\title{
Prevalence of thyroid disorders and the correlation of thyroid profile with liver enzymes, serum activin-A and follistatin during the treatment of patients with chronic hepatitis $C$ genotype 1 and 4
}

\author{
Kronik hepatit C genotip 1 ve 4 hastaların tedavisi sırasında tiroid bozuklukları prevalansı ve \\ tiroid profili ile karaciğer enzimleri, serum activin-A ve follistatin arasındaki ilişki
}

Ahmed Mohammed Ashshi ${ }^{1}$, Adel Galal El-Shemi ${ }^{1,3}$, Adnan AlZanbagi $^{2}$, Bassem Refaat ${ }^{1}$

\begin{abstract}
Objectives Chronic hepatitis $\mathrm{C}(\mathrm{CHC})$ and peg-interferon- $\alpha$ (Peg-INF- $\alpha$ ) modulate serum activins and follistatin and are associated with thyroid disorders (TD). The aim of this study was to determine the frequency of $\mathrm{CHC}$ induced TD and to investigate the correlation of liver damage, serum activin-A and follistatin with the thyroid function parameters and thyroid autoantibodies.
\end{abstract}

Methods: The study was cross-sectional and sera were obtained from 132 patients with $\mathrm{CHC}$ who were divided into 3 groups: 56 patients with no treatment, 30 after 24 weeks of Peg-INF- $\alpha$ and 46 at the end of 48 weeks Peg-INF- $\alpha$. Thyroid stimulating hormone (TSH), free thyroxin (FT4), thyroid antibodies (Tabs), serum activin-A and follistatin levels were measured using ELISA.

Results: Thyroid disorders were detected in 15\% $(n=20)$, more frequent in females (70\%) and the majority were autoimmune thyroiditis $(80 \%)$. TSH receptor antibodies (TSHRAbs) were significantly prevalent compared to the other antibodies $(p<0.05)$ and significantly increased in the 24 weeks group $(p<0.05)$. TSH and FT4 correlated significantly with liver enzymes $(p<0.05)$. There was no significant difference in activin-A and follistatin values between thyroid disorder and euthyroids. However, significant correlations were found between TSHR-Abs concentration with follistatin, activin-A and activin/follistatin ratio $(p<0.05)$.

Conclusion: Thyroid disorders induced by $\mathrm{CHC}$ and/or PegINF- $\alpha$ were common in our patients, more prevalent in females and the majority are autoimmune. Additionally, activinA and/or follistatin could be involved in the induction/aggravation of TSHR-Abs. Further studies are needed to confirm our findings and to explore the mechanisms by which $\mathrm{CHC}$ induces thyroid disorders. J Clin Exp Invest 2014; 5 (3): 343353

Key words: Chronic hepatitis C, thyroid disorder, activin-A, follistatin, Saudi Arabia

\section{ÖZET}

Amaç: Kronik hepatit $\mathrm{C}(\mathrm{KHC})$ ve Peg-interferon- alfa (Peg-INF- $\alpha$ ) serum aktivinleri ve follistatini düzenler ve tiroid hastalıkları (TH) ile birliktedir. Bu çalışmanın amacı KHC'nin indüklediği TH sıklığını belirlemek ve karaciğer hasarı, serum activin-A ve follistatin'in tiroid fonksiyonları ve tiroid otoantikorları ile ilişkisini araştırmaktır.

Yöntemler: Bu çalışma kesitsel olup, 3 gruba ayrılan 132 KHC'li hastadan serumları alınmıştır: Tedavisiz 56 hasta, 24 haftalık Peg-INF- $\alpha$ tedavisi almış 30 hasta ve PegINF- $\alpha$ tedavisi tamamlanmış 46 hasta. Tiroid stimülan hormon (TSH), serbest tiroksin (FT4) ve tiroid otoantikorları, serum activin-A ve follistatin düzeyleri ELISA yöntemiyle ölçüldü.

Bulgular: Hastaların \%15'inde $(n=20)$ tiroid hastalığı saptandı, bunların çoğunluğu (\%80) otoimmün tiroidit olup, kadınlarda daha sık (\%70) idi. TSH reseptör antikorları (TSHR-Abs), diğer antikorlardan anlamlı yüksek bulundu $(p<0,05)$ ve 24 haftalık tedavi grubunda anlamlı artmıştı $(p<0,05)$. TSH ve FT4 karaciğer enzimleri ile anlamlı körele idi $(p<0,05)$. Tiroid hastalığı olanlarla ötiroid olanlar arasında activin-A ve follistatin değerleri bakımından anlamlı fark yoktu $(p>0,05)$. Ancak TSHR-Abs ile follistatin, activin-A ve activi/follistatin oranı arasında anlamlı korelasyonlar saptandı $(p<0,05)$.

Sonuç: Hastalarımızda KHC ve/veya Peg-INF-a'nın indüklediği tiroid bozuklukları yaygın olup, bunların çoğu otoimmundur ve kadınlarda daha sık idi. İlaveten, activin-A ve/veya follistatin TSHR-Abs oluşumu/agrevasyonunda etkili olabilir. Sonuçlarımızı doğrulamak ve KHC'daki tiroid hastalıkları oluşum mekanizmalarını açıklamak için ilave çalışmalara gereksinim vardır.

Anahtar kelimeler: Kronik hepatit C, tiroid hastalığı, activin-A, follistatin, Suudi Arabistan

\footnotetext{
${ }^{1}$ Laboratory Medicine Department, Faculty of Applied Medical Sciences, Umm Al-Qura University, Al Abdeyah, Makkah, KSA. ${ }^{2}$ Gastroenterology Department, King Abdullah Medical City, Makkah, 21955, KSA.

${ }^{3}$ Department of Pharmacology, Faculty of Medicine, Assiut University, Egypt
}

Correspondence: Bassem Refaat,

Laboratory Medicine Dept. Faculty of Applied Medical Sciences Umm Al-Qura University Makkah, KSA Email: Bassem.refaat@yahoo.co.uk 


\section{INTRODUCTION}

The treatment of chronic hepatitis $\mathrm{C}$ infection $(\mathrm{CHC})$ is currently based on a combination of pegylated interferon- $\alpha$ (Peg-INF- $\alpha$ ) and ribavirin and the treatment duration depends on the viral genotype [1]. One of the most prevalent CHC and Peg-INF- $\alpha$ extrahepatic disorders is thyroid dysfunction [2]. Types of thyroid disorders (TD) associated with HCV and Peg-INF- $\alpha$ based therapy range from subclinical to overt hypo- and hyperthyroidism due to autoimmune and non-autoimmune predisposition [3]. The prevalence of HCV and Peg-INF- $\alpha$ induced thyroiditis ranges between $2.5 \%$ to $35 \%[4,5]$.

The most common form of thyroid autoimmunity during $\mathrm{CHC}$ is the presence of thyroid antibodies (Tabs) without clinical disease [6]. Antibodies include thyroid peroxidase antibodies (TPO-Abs), TSH receptor antibodies (TSHR-Abs) and thyroglobulin antibodies (TG-Abs); and patients may be positive for one or more of these antibodies $[3,7,8]$. However, about $50 \%$ of patients who develop thyroid dysfunction during Peg-IFN- $\alpha$ therapy do not develop Tabs, suggesting that thyroid dysfunction could also be mediated by a direct effect on thyroid cell function rather than immune mediated mechanism [9]. IFN induced non-autoimmune thyroiditis exists in two forms, destructive thyroiditis and hypothyroidism [3].

Activins are cytokines that belong to the transforming growth factor- $\beta$ superfamily and follistatin is the main regulator of the local bioactivity of activins since binding of activins to follistatin is almost irreversible [10]. Activins are involved in the pathogenesis of inflammatory and autoimmune human diseases [11,12]. Activin-A can have both pro- and anti-inflammatory actions depending on both cellular and temporal contexts [12].

Activins are secreted in the cytoplasm of the thyroid follicle cells $[13,14]$, indicating an active synthesis and it has been suggested that they are involved in the stimulation of DNA synthesis and proliferation of thyrocytes of porcine thyroid cells in vivo [15]. The expression of activins' intracellular mediators (Smad) have also been reported in thyroid cells and in the nucleus of thyroid tumour cells, indicating propagation of activin signalling in thyrocytes [16].

Additionally, a slight increase in activin-A was associated with hyperthyroidism [17]. While a significant increase of activin-A was associated with hypothyroidism [18]. The evidence that immunostaining for activin $\mathrm{A}$ in thyroid follicular cells is more intense in patients with Graves' disease than in normal subjects [19]. Serum levels of activin-A are higher in goitrous patients with autoimmune thyroiditis more than control subjects [18].

Currently, there is no report from Saudi Arabia or other Arabian Gulf countries about the prevalence of thyroiditis in $\mathrm{CHC}$ patients with or without treatment with Peg-INF- $\alpha$ based therapy. Additionally, we have previously reported that $\mathrm{CHC}$ and Peg-INF- $\alpha$ based therapy modulate the serum concentrations of activin-A and follistatin $[20,21]$. The present study was therefore conducted to measure the frequency and types of thyroid disorders associated with $\mathrm{CHC}$ and/or its therapy in treatment naïve Saudi patients diagnosed with HCV genotype 1 and 4. We also measured the correlation between liver damage, serum activin-A, follistatin and activin/follistatin ratio with the thyroid function parameters at the time of diagnosis, after 24 weeks of treatment initiation and at the end of the treatment protocol of 48 weeks.

\section{METHODS}

\section{Ethical approval}

The study was approved by the institutional review board and ethics committee of King Abdullah Medical City (IRB 12-028). All samples were collected following obtaining informed written consent from all the participants.

\section{Study design}

This was a cross-sectional study. Serum samples were collected from 132 Saudi patients diagnosed with $\mathrm{CHC}$ genotype 1 or 4 and for whom positive polymerase chain reaction following reverse transcription was positive for HCV RNA according to the principle inclusion and exclusion criteria (table 1). The patients were divided according to the timing of the samples into 3 groups:

A. No treatment group (NT): This group included 56 patients according to the inclusion and exclusion criteria and who did not start their treatment protocol. The patients consisted of 24 males and 32 females with age range (22-70 years). Thirty two cases were positive for viral genotype 4 and 24 for genotype 1 .

B. 24 weeks group (24W): This group consisted of samples collected from 30 patients who had Peg-INF- $\alpha$ based therapy for 24 weeks. The group included 20 males and 10 females with age range of (21-64 years). Sixteen cases were genotype 4 and 14 genotype 1 . 
Table 1. Principles inclusion and exclusion criteria

\begin{tabular}{|c|c|}
\hline Principal inclusion criteria & Principle exclusion criteria \\
\hline Patient age $\geq 18$ years. & Patient age $<18$ years. \\
\hline HCV RNA positive & Previous non-responders/relapse \\
\hline No concurrent infection with HBV or HIV & Solid organ transplant (renal, heart, or liver, etc.) \\
\hline Dual therapy using peg-INF- $\alpha 2 \mathrm{a}$ or $2 \mathrm{~b}$ with ribavirin & Mono- or triple based therapy \\
\hline Treatment naïve patients & Autoimmune condition (type $1 \mathrm{DM}$, rheumatoid arthritis, etc.) \\
\hline $\begin{array}{l}\text { Compensated liver disease (e.g. no liver cirrhosis, fail- } \\
\text { ure or cancer) \& APRI } \leq 1.2\end{array}$ & History or current thyroid disease \\
\hline Acceptable hematological and biochemical indices & Uncontrolled type 2 DM and HTN \\
\hline No or controlled type $2 \mathrm{DM}$ and hypertension & Concurrent chronic disease (Renal failure, CHD, etc.) \\
\hline
\end{tabular}

DM: Diabetes mellitus, HTN: Hypertension, CHD: Coronary heart disease

C. End of treatment group (ET): The final group included samples collected from 46 patients at the end of a 48 weeks treatment protocol. The patients were 24 males and 22 females with age range (1961 years). Genotype 4 and 1 were positive in 28 and 18 cases, respectively.

All treated patients received PEG-INF- $\alpha-2 a$ (Pegasys, Roche, Basel, Switzerland) at a dosage of $180 \mu \mathrm{g}$ per week in combination with daily dose of ribavirin (Copegus, Roche) based on the body weight (1000 mg if $<75 \mathrm{~kg}$ or $1200 \mathrm{mg}$ if $\geq 75 \mathrm{~kg}$ ).

The results of liver function parameters and viral load at the time of sample collection were performed as part of the routine laboratory follow-up.

The study measured the prevalence of thyroid disorders and the different types of thyroid antibodies in all groups. We also measured concentrations of activin-A and follistatin in all samples and positive samples for the different thyroid antibodies were compared to the negative samples within the same group. Furthermore, serum TSH and free T4 were measured in all samples and correlation studies were conducted with the different thyroid antibodies, liver enzymes, activin-A and follistatin.

\section{Calculation of APRI}

APRI was calculated using the following equation: (AST/upper limit of normal)/platelet count (X 109/L) $X$ 100. The interpretation of the APRI results was performed according to previously published studies $[20,21]$. All samples were collected following the calculation of their APRI and only samples with $\leq$ 1.2 were included into the study to avoid samples collected from patients suffering from liver cirrhosis.

\section{Measurement of TSH and free T4}

The quantitative measurement of thyroid stimulating hormone (TSH) and free thyroxin hormone (FT4) was done using electro-chemiluminescence immunoassay (ECLIA) on Cobas e411 (Roche Diagnostics International Ltd, Switzerland) according to the manufacturer protocol. The reference range according to the manufacturer for TSH and free T4 was $0.27-4.20 \mu \mathrm{lU} / \mathrm{mL}$ and $12-22 \mathrm{pmol} / \mathrm{L}$, respectively. The detection sensitivity was $0.005 \mu \mathrm{lU} / \mathrm{mL}$ for $\mathrm{TSH}$ and $0.3 \mathrm{pmol} / \mathrm{L}$ for FT4. The intra- and interassay coefficients of variations for FT4 were 1.7 and $3.9 \%$ and for TSH were $1.4 \%$ and $3.4 \%$, respectively. The diagnosis and classification of thyroid abnormalities were according to the guidelines of the National Academy of Clinical Biochemistry (NACB) for laboratory diagnosis and monitoring of thyroid diseases [22]. Hypothyroidism was considered when TSH > $4.5 \mu \mathrm{lU} / \mathrm{mL}$ and the level of FT4 defined the type as either primary (FT4 $<12 \mathrm{pmol} / \mathrm{L})$ or subclinical (FT4 $\geq 12 \mathrm{pmol} / \mathrm{L}$ ). Hyperthyroidism was considered for $\mathrm{TSH}<0.10 \mu \mathrm{lU} / \mathrm{mL}$ and FT4 $>22 \mathrm{pmol} / \mathrm{L}$.

\section{Measurement of thyroid autoantibodies}

ELISA was used to detect the $\lg G$ antibodies against TSH receptor (TSHR-abs), TPO (TOP-abs) and TG (TG-abs) (Human Diagnostica, Germany) by following the manufacturer's instructions and the optical density of the plates was measured within 10 min using a plate reader at $450 \mathrm{~nm}$. The cut-off values according to the manufacturer's instructions for a positive test for TSHR-abs was $>1.5 \mathrm{IU} / \mathrm{l}$, negative was $<1 \mathrm{IU} / \mathrm{I}$ and equivocal was between 1.1-1.5 IU/I. Results for TPO antibodies were considered negative if $<80 \mathrm{WHO}-\mathrm{IU} / \mathrm{ml}$, equivocal between 80 - 
$150 \mathrm{WHO}-\mathrm{IU} / \mathrm{ml}$ and positive if $>150 \mathrm{WHO}-\mathrm{IU} / \mathrm{ml}$. For TG antibodies, results were considered negative if $<80 \mathrm{WHO}-\mathrm{IU} / \mathrm{ml}$, equivocal if between $80-200$ $\mathrm{WHO}-\mathrm{IU} / \mathrm{ml}$ and positive if $>200 \mathrm{WHO}-\mathrm{IU} / \mathrm{ml}$.

The IMTEC-TSH Receptor-Antibodies ELISA has a sensitivity of $100 \%$ and a specificity $>95 \%$. The kit has a lower detection limit of $0.21 \mathrm{IU} / \mathrm{L}$ and the inter-assay and intra-assay imprecision is CV $10.9-12.9 \%$ and CV $2.2-7.1 \%$, respectively. The IMTEC-TPO-Antibodies has a sensitivity of $92.9 \%$ and a specificity of $97.6 \%$, and the analytical sensitivity of the kit is $\leq 3.0 \mathrm{WHO}-\mathrm{IU} / \mathrm{ml}$. The interassay and intra-assay imprecision is CV $11.1 \%$ and CV 8.9\%, respectively. The IMTEC-TG-Antibodies ELISA kit has a sensitivity of $92.8 \%$ and a specificity of $97.9 \%$, and the analytical sensitivity of the kit is $\leq 6.0 \mathrm{WHO}-\mathrm{IU} / \mathrm{ml}$. The inter-assay and intra-assay imprecision is CV $8.2 \%$ and CV $8.3 \%$, respectively.

\section{Measurement of human activin-A and follistatin serum concentrations}

ELISA was used for quantitative measurement of human activin-A and follistatin in all samples (R\&D systems, USA) as previously described. As reported by the manufacturer, the lowest detection limit of activin-A by the used kit is $3.7 \mathrm{pg} / \mathrm{mL}$ and the upper limit is $1500 \mathrm{pg} / \mathrm{mL}$. The intra-assay and inter-assay precisions of the kit are $4.3 \%$ and $5.8 \%$, respectively. The kit cross reacts by $0.2 \%$ and $0.45 \%$ with
inhibin-A and activin-AB, respectively. The detection range of the follistatin kit is $250-16000 \mathrm{pg} / \mathrm{mL}$ and the minimum detectable dose is $83 \mathrm{pg} / \mathrm{mL}$. The intra-assay and inter-assay precisions are $<3 \%$ and $<9 \%$, respectively. Activin-A/follistatin ratio index (AFRI) was calculated as follow: [Activin-A/follistatin $x$ 100].

\section{Statistical analysis}

Statistical analysis of the results was performed using SPSS version 20. The Chi square (X2) test was used for frequency analysis. According to data normality, either student's $T$ test or Mann-Whitney $U$ test was used to compare between 2 groups. Furthermore, one way ANOVA followed by Tukey post hoc test or Kruskal-Wallis followed by Dunn's post hoc test were used to compare between more than 2 groups depending on the data homogeneity. Correlations were determined using Pearson's test. $\mathrm{P}$ value $<0.05$ was considered significant.

\section{RESULTS}

\section{Demographic results and general laboratory parameters}

There was no significant difference in the mean age, the distribution of gender, viral genotype and viral load at diagnosis, liver enzymes and thyroid hormones either between the three study groups or within each group (table 2).

Table 2. Demographic and laboratory characteristics of all study participants according to the different study groups

\begin{tabular}{|c|c|c|c|}
\hline & $\begin{array}{l}\text { No treatment } \\
(n=56)\end{array}$ & $\begin{array}{l}24 \text { weeks } \\
(n=30)\end{array}$ & $\begin{array}{l}\text { End of treatment } \\
(n=46)\end{array}$ \\
\hline Age (years) & $50.1 \pm 16.3$ & $46.4 \pm 13.3$ & $44.1 \pm 14.6$ \\
\hline \multirow{2}{*}{ Gender } & $46.4 \%$ & $66.7 \%$ & $39 \%$ \\
\hline & $53.6 \%$ & $33.3 \%$ & $61 \%$ \\
\hline \multirow{2}{*}{ Genotype } & $43 \%$ & $46.7 \%$ & $50 \%$ \\
\hline & $57 \%$ & $53.3 \%$ & $50 \%$ \\
\hline Viral Load at diagnosis $(\mathrm{IU} / \mathrm{mL})$ & $1125694 \pm 555544$ & $999187 \pm 400348$ & $1048288 \pm 303944$ \\
\hline Albumin (g/dL) & $3.8 \pm 0.47$ & $4.06 \pm 0.22$ & $4.06 \pm 0.42$ \\
\hline ALP (IU/L) & $116 \pm 55.6$ & $79.4 \pm 39.1$ & $93.7 \pm 51.6$ \\
\hline ALT (IU/L) & $45.5 \pm 19.9$ & $43.2 \pm 25.6$ & $34.8 \pm 23.7$ \\
\hline AST (IU/L) & $47 \pm 18.6$ & $38.8 \pm 17.8$ & $33.4 \pm 15.4$ \\
\hline APRI & $0.68 \pm 0.37$ & $0.59 \pm 0.31$ & $0.64 \pm 0.35$ \\
\hline $\mathrm{TSH}(\mu \mathrm{IU} / \mathrm{L})$ & $2.4 \pm 1.1$ & $2.7 \pm 1.5$ & $3 \pm 2.1$ \\
\hline FT4 (pmol/L) & $14.2 \pm 3.3$ & $14 \pm 3.8$ & $13.4 \pm 3.8$ \\
\hline
\end{tabular}




\section{Prevalence and types of thyroiditis in the different study groups}

Thyroid disorder was detected in 20 patients (15\%) of the study participants. Six cases were found in the 'No treatment' group, 8 patients in the '24W group' and 6 in the 'End of treatment' group. Regarding gender, $70 \%$ of thyroiditis was observed in females $(n=14)$ and $30 \%$ in males $(n=6)$ with female: male ratio 2.3:1. Half of the patients $(n=10,50 \%)$ had subclinical thyroiditis and the remainder had clinical thyroiditis. The prevalence of hypothyroidism and hyperthyroidism was $60 \%$ vs. $40 \%$, respectively (Figure 1). Sixteen patients had autoimmune thyroiditis $(80 \%)$ and four had non-autoimmune thyroid disease (20\%) (Figure 2).
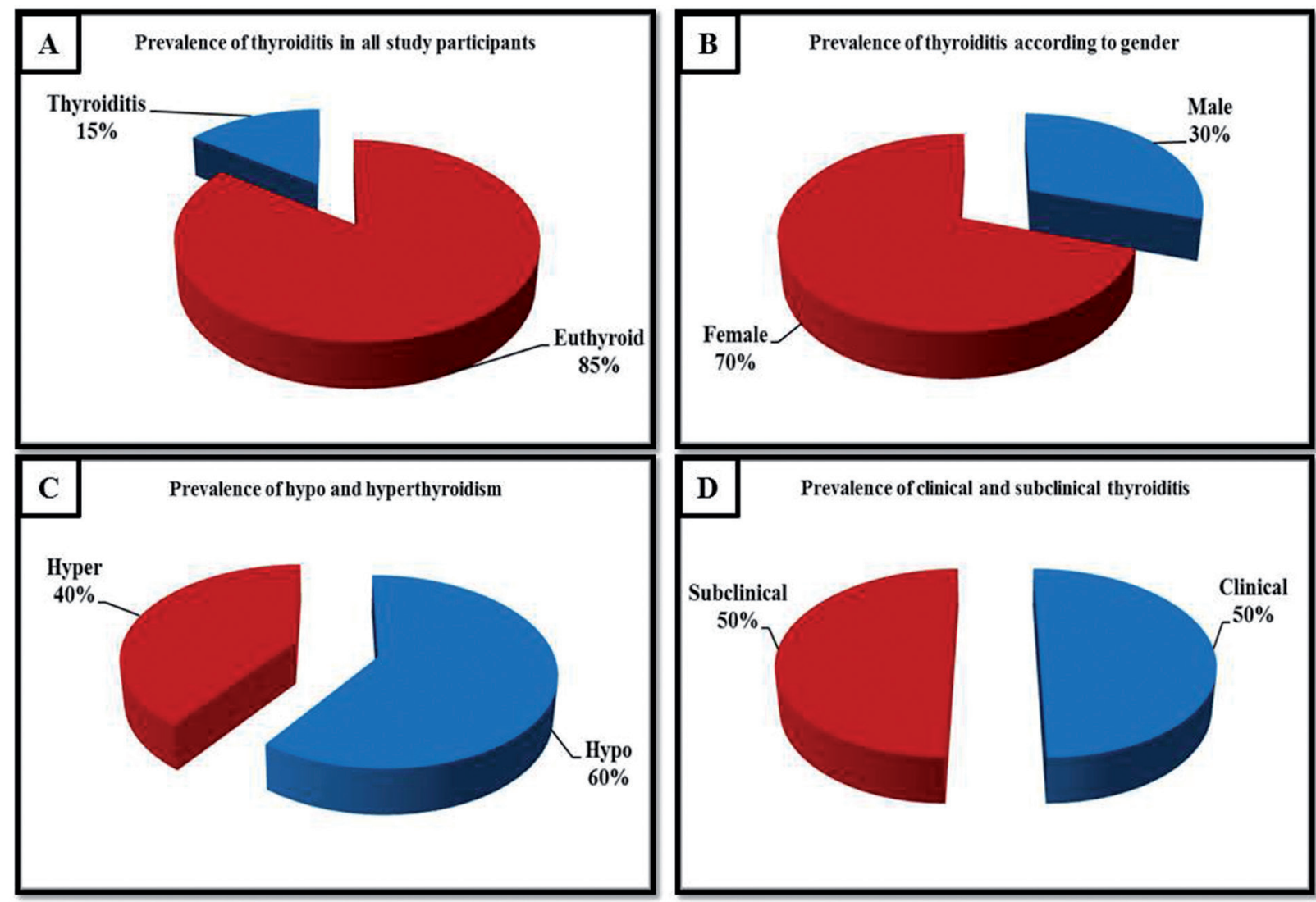

Figure 1. The prevalence of thyroiditis $(A)$ in all study participants, $(B)$ in male and female participants $(C)$ according to hypo- or hyperthyroidism and (D) according to clinical and subclinical presentation

\section{Prevalence of thyroid antibodies in the different study groups}

The three thyroid antibodies were detected in all groups except for the 'No treatment group' in which all cases were negative for TPO antibodies (Figure 3 ). The total number of positive cases in the 3 groups for TSHR-Abs ( $n=64,48.4 \%$ ) was significantly higher when compared with the other 2 antibodies $(P=0.1 X 10-4)$ (Figure 3). Furthermore, there was no significant difference $(P=0.4)$ between the number of positive cases for antibodies against TPO (n $=6,4.5 \%)$ when compared to TG $(n=16,12.1 \%)$.

TSHR-Abs were detected in the 'NT' $(n=20$, $35.7 \%)$, ' $24 \mathrm{~W}$ ' $(\mathrm{n}=22,73.3 \%)$ and ' $\mathrm{ET}$ ' $(\mathrm{n}=22$,
$47.8 \%)$ groups. There was a significant increase in the prevalence of TSHR-Abs following treatment with Peg-INF- $\alpha$ for 24 weeks $(P=0.02)$ followed by a non-significant decline at the end of the 48 weeks treatment protocol. However, there was no significant difference in the number of positive cases between the 'NT' vs. 'ET' groups and the '24W' vs. 'ET' groups $(P>0.05)$ (Figure 3$)$.

Serum concentrations of TSHR-Abs showed a similar pattern to the prevalence as a significant increase was detected between the '24W' ( $4.25 \pm$ $1.08 \mathrm{IU} / \mathrm{mL})$ and 'NT' groups $(2.1 \pm 0.36 \mathrm{IU} / \mathrm{mL})(\mathrm{P}$ $=0.0004)$. Additionally, a significant difference was observed between the '24W' and 'ET' $(2.3 \pm 0.49 \mathrm{IU} /$ 
$\mathrm{mL})$ groups $(P=0.001)$. There was no significant difference between the 'NT' and 'ET' groups $(P=0.4)$ (Figure 3). Furthermore, a significant increase in the concentration of TSHR-Abs was observed in the au- toimmune thyroiditis $(3.88 \pm 0.43 \mathrm{IU} / \mathrm{mL})$ compared to the positive cases for TSHR-Abs in the euthyroid group $(2.1 \pm 0.25 \mathrm{IU} / \mathrm{mL})(P=0.003)$ (Figure 3).

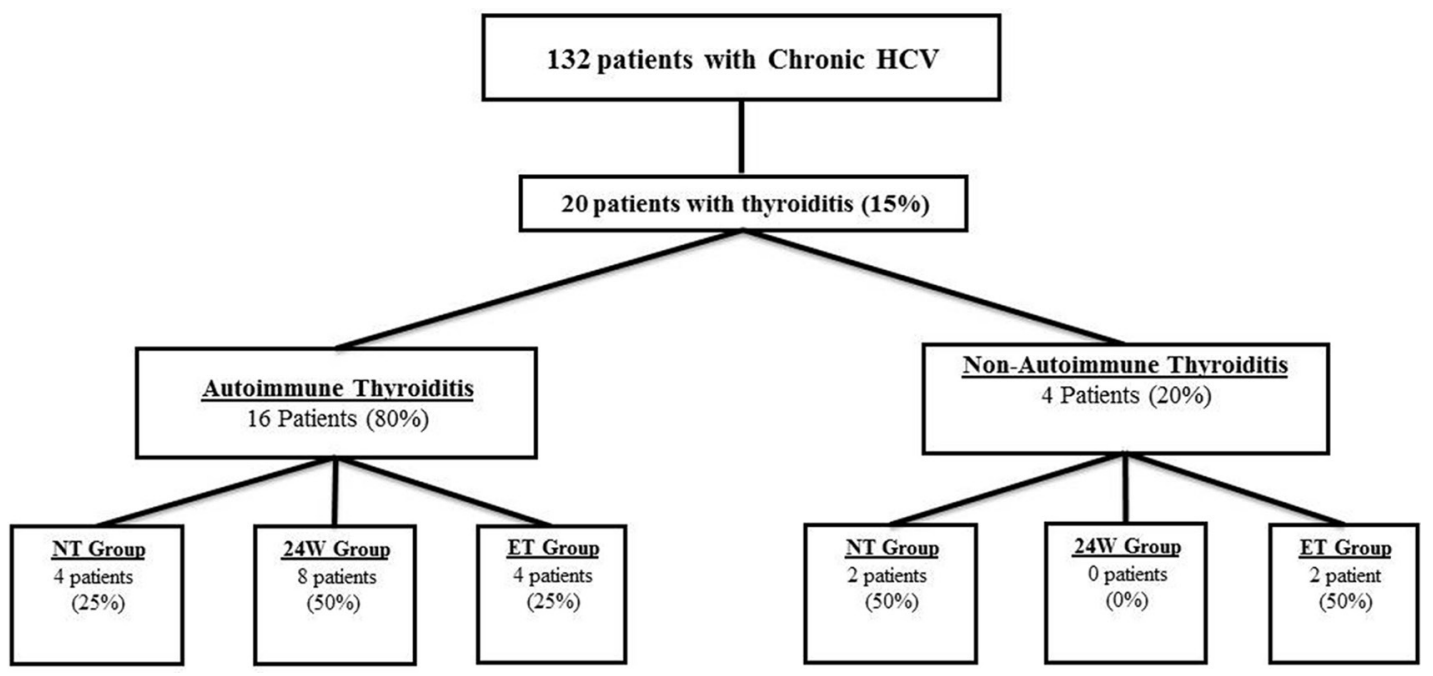

Figure 2. The prevalence of thyroiditis in the 132 study participants and the prevalence in the 'No treatment' group (NT), '24 weeks' group (24W) and the 'End of Treatment' group (ET) according to auto- and non-autoimmune

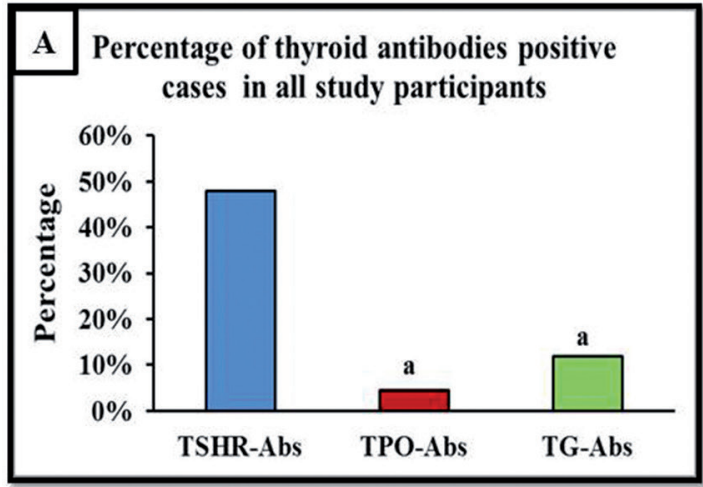

B $\quad$ Percentage of positive cases for thyroid antibodies in the different groups
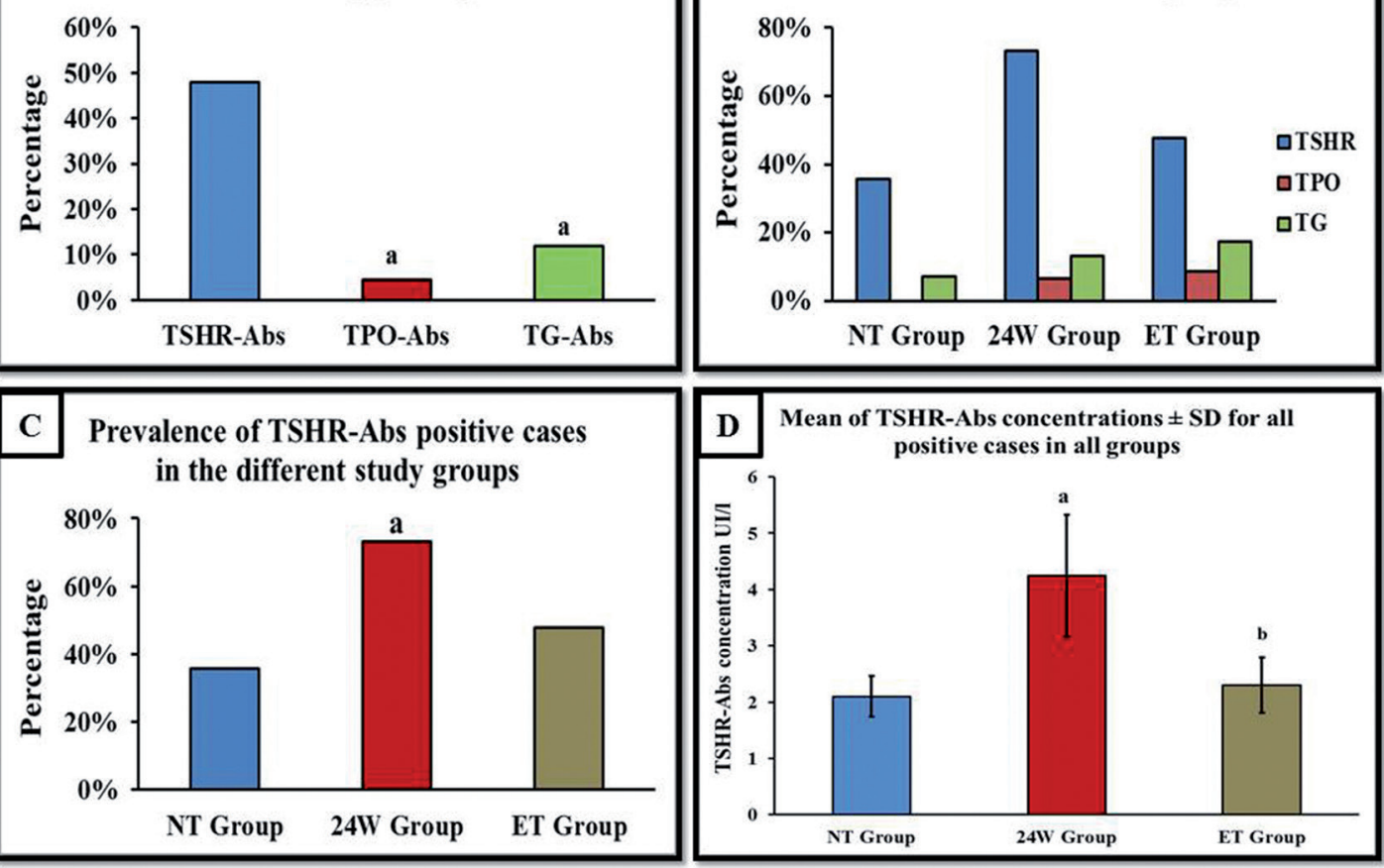

Figure 3. Prevalence of (A) thyroid autoantibodies in all study participants, (B) different thyroid autoantibodies according to study groups, (C) TSHR-Abs according to study groups ( $a=p<0.05$ compared to NT group) and (D) mean \pm SD of serum TSHR-Abs concentrations in the positive cases in each study group $(a=p<0.05$ compared to NT group and $b=p<0.05$ compared to $24 \mathrm{~W}$ group). 

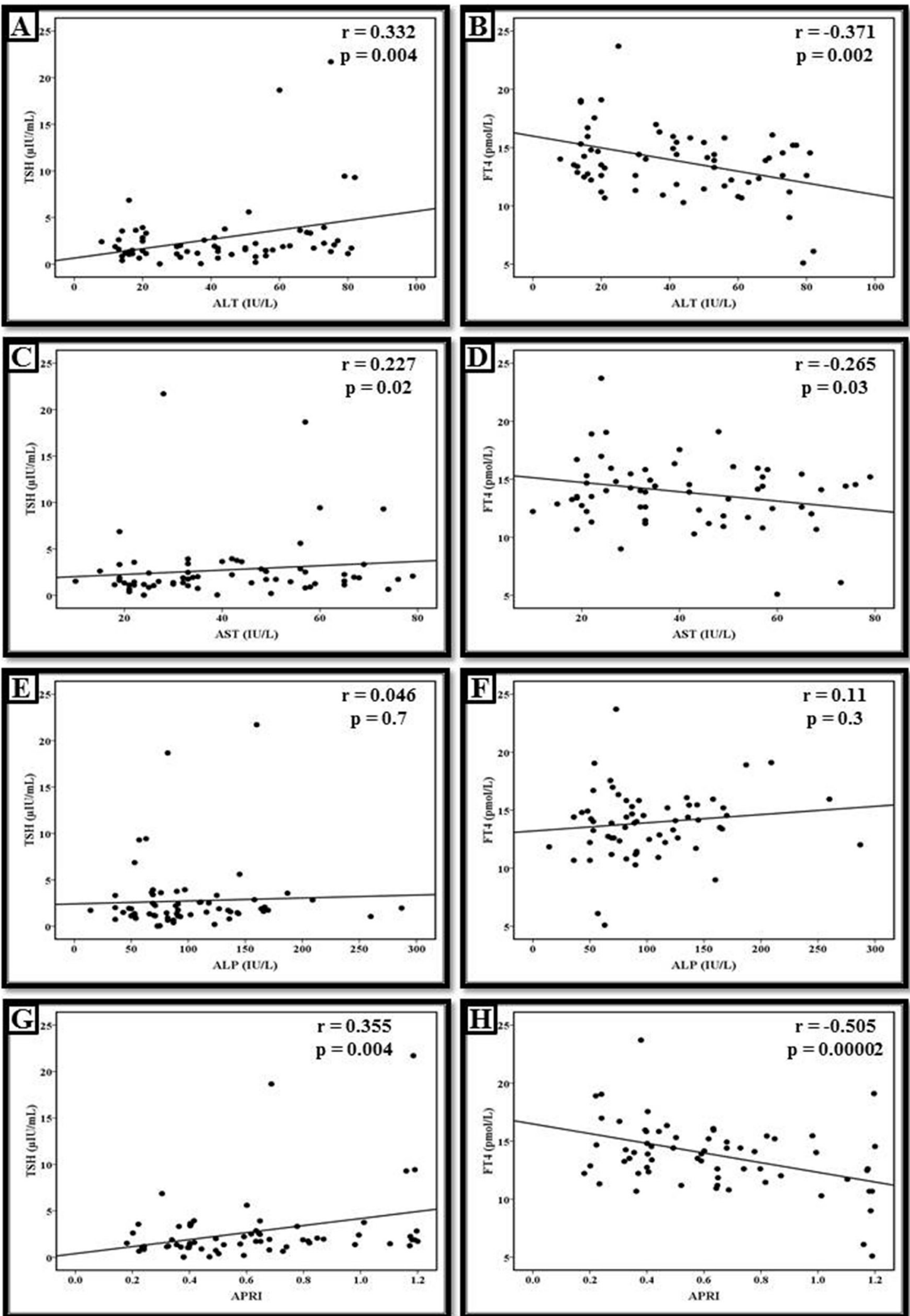

Figure 4. Correlation of ALT (A \& B), AST (C \& D), ALP (E \& F) and ASPRI (G \& H) with TSH (left column) and free T4 (Right column) 


\section{Correlation between liver enzymes and thyroid hormones}

Liver enzymes and APRI correlated significantly with TSH and free T4 (Figure 4). ALT significantly correlated with TSH $(r=0.332, P=0.004)$ and inversely with free $\mathrm{T} 4(r=-0.371, P=0.002)$. Additionally, a similar significant pattern of correlation, was observed for AST with TSH $(r=0.277, P=0.02)$ and free T4 ( $r=-0.265, P=0.03)$. The strongest significant correlation with thyroid hormones was observed with APRI $(r=0.355, P=0.004 ; r=-0.505$, $\mathrm{P}=0.00002$ ) for TSH and free T4, respectively. ALP did not correlate with neither TSH $(r=0.046, \mathrm{P}=$ $0.7)$ nor free $\mathrm{T} 4(\mathrm{r}=0.11, \mathrm{P}=0.3)$ (Figure 4).

\section{Activin-A and follistatin in hepatitis $\mathrm{C}$ induced thyroiditis}

There was no significant difference in serum activin-A, follistatin and activin/follistatin ratio (A/F) between autoimmune thyroiditis and euthyroid cases (Table 3) and between positive and negative cases for TSHR-Abs within each study groups $(P>0.05)$ (Table 4).

There was a significant negative correlation between serum activin-A and TSHR-Abs concentration $(r=-0.206, P=0.01)$. Furthermore, a significant positive correlation for TSHR-Abs concentration with follistatin $(r=0.303, P=0.0001)$ and a significant inverted correlation with A/F ratio $(r=-0.342, P$ $=0.0005$ ) was observed (Table 5).

Table 3. Mean of activin-A, follistatin and AFRI ratio \pm SD in autoimmune thyroiditis (AT) and euthyroidism (EU) within each of the study group. No significant difference was observed between positive and negative cases within each group.

\begin{tabular}{llllccc}
\hline & \multicolumn{2}{c}{ NT group } & \multicolumn{2}{c}{ 24W group } & \multicolumn{2}{c}{ ET group } \\
\cline { 2 - 7 } & \multicolumn{1}{c}{ EU } & \multicolumn{1}{c}{ AT } & EU & AT & EU & \multicolumn{1}{c}{ AT } \\
\hline Activin-A $(\mathrm{pg} / \mathrm{mL})$ & $864.2 \pm 233$ & $822.8 \pm 163$ & $424 \pm 193$ & $382.7 \pm 107$ & $471.7 \pm 127.1$ & $695.5 \pm 227.1$ \\
Follistatin $(\mathrm{pg} / \mathrm{mL})$ & $473.9 \pm 201.5$ & $408.6 \pm 265.6$ & $807.8 \pm 285$ & $644 \pm 105.9$ & $684.9 \pm 362.2$ & $425.8 \pm 187.1$ \\
AFRI & $195 \pm 71$ & $248 \pm 87$ & $77 \pm 27$ & $61 \pm 22$ & $118 \pm 31$ & $170 \pm 74$ \\
\hline
\end{tabular}

Table 4. Mean of activin-A, follistatin and AFRI \pm SD in positive (+) and negative (-) cases of TSHR-Abs within each of the study group. No significant difference was observed between positive and negative cases within each group.

\begin{tabular}{lllllll}
\hline & \multicolumn{2}{c}{ NT group } & \multicolumn{2}{c}{ 6MT group } & \multicolumn{2}{c}{ ET Group } \\
\cline { 2 - 7 } & - TSHR-Abs & + TSHR-Abs & - TSHR-Abs & + TSHR-Abs & - TSHR-Abs & + TSHR-Abs \\
\hline Activin-A $(\mathrm{pg} / \mathrm{mL})$ & $830.8 \pm 348.6$ & $929.1 \pm 248.8$ & $508 \pm 232$ & $479 \pm 174.7$ & $540.5 \pm 189.3$ & $478 \pm 120$ \\
Follistatin $(\mathrm{pg} / \mathrm{mL})$ & $451.4 \pm 193.6$ & $507.6 \pm 202.8$ & $1076.8 \pm 382$ & $850.5 \pm 277.6$ & $674.8 \pm 211.5$ & $761.2 \pm 227.2$ \\
AFRI & $194 \pm 68$ & $207 \pm 81$ & $59 \pm 30$ & $78 \pm 32$ & $149 \pm 81$ & $105 \pm 42$ \\
\hline
\end{tabular}

Table 5. Results of correlation analysis using Pearson's test for serum activin-A, follistatin and AFRI with TSH, FT4, TSHR-Abs, TPO-Abs and TG-Abs

\begin{tabular}{lllllll}
\hline & & TSH & FT4 & TSHR-Abs & TPO-Abs & TG-Abs \\
\hline Activin-A & $\mathbf{r}$ & 0.023 & -0.064 & $-0.206^{*}$ & 0.027 & 0.089 \\
& $\mathbf{p}$ & 0.7 & 0.4 & 0.01 & 0.7 & 0.3 \\
\hline Follistatin & $\mathbf{r}$ & -0.091 & -0.053 & $0.304^{*}$ & -0.086 & 0.005 \\
& $\mathbf{p}$ & 0.7 & 0.5 & 0.0002 & 0.3 & 0.9 \\
\hline AFRI & $\mathbf{r}$ & 0.019 & 0.062 & $-0.342^{*}$ & 0.079 & 0.007 \\
& $\mathbf{p}$ & 0.8 & 0.4 & 0.00001 & 0.3 & 0.9 \\
\hline
\end{tabular}




\section{DISCUSSION}

The current research is the first to report the prevalence and types of thyroid disorders associated with $\mathrm{CHC}$ infection with or without Peg-INF- $\alpha$ therapy in treatment naïve Saudi patients. Furthermore, this is the first study to report significant correlations between serum concentrations of TSH receptor antibodies with serum Follistatin, activin-A and activin$\mathrm{A} /$ follistatin ratio. However, there was no significant difference in serum concentrations of activin-A and follistatin between positive and negative cases for TSH receptor antibodies. Our results suggest that activin-A and/or follistatin may play a role in the development of TSH receptor antibodies. Finally, significant correlations between ALT, AST and APRI were also observed with the levels of serum TSH and T4, suggesting that liver damage following $\mathrm{CHC}$ is associated with hypothyroidism.

There are several drawbacks in our study. A limitation of our study is that it presents data from a small sample size and increasing the number of patients would increase the statistical power of the study to reflect the actual prevalence of $\mathrm{CHC}$ and Peg-INF- $\alpha$ induced thyroid diseases in Saudi patients. However, we were able to detect thyroid disorders in $15 \%$ and $\mathrm{TSH}$ receptors antibodies in $48.4 \%$ of the study population, suggesting that thyroid disorders are a common complication of $\mathrm{CHC}$ and its currently used treatment in Saudi patients.

A further limitation is that we did not measure free T3, total T3 and total T4 to appropriately evaluate the thyroid functions. Nevertheless, the routine screening and clinical biochemical diagnosis of thyroid disorders are essentially based on measuring TSH and free T4. Another limitation is that we adopted a cross-sectional design and performing a longitudinal prospective study would reveal the accurate timing of thyroiditis development and would allow proper follow-up for patients to determine the prognosis and rate of recovery.

The reported prevalence of HCV and PegINF- $\alpha$ induced thyroiditis in developed countries ranges between $2.5 \%$ to $35 \%$ [23]. Currently there are only two available reports from the Middle East and the prevalence ranged between 8.5 and $20 \%$ $[24,25]$. Females are at higher risk of developing thyroiditis following $\mathrm{CHC}$ and peg-INF-a [3]. Furthermore, hypothyroidism has also been reported to be more common than hyperthyroidism $[26,27]$. Similar results were also reported form the UK[28], Taiwan [29] and Australia [30]. Our study supports the previous findings as it showed an overall $15 \%$ prevalence of $\mathrm{CHC}$ and peg-INF- $\alpha$ induced thyroid disorders in Saudi patients, the majority were females and $60 \%$ of the patients had hypothyroidism.

Thyroid autoimmunity are significantly more common with $\mathrm{CHC}$, which is associated with the development of the different types of thyroid autoantibodies (Tabs) [31]. Patients infected with HCV present $40-42 \%$ of detectable Tabs levels; whereas in patients with hepatitis $B$ virus, the index varies from 5 to $10 \%[31]$. Our results correlate with the previous studies as we have detected Tabs in $60 \%$ of our patients. However, the higher prevalence in our study could be due to differences in the study design and the sample size, which is smaller in our study, or different environmental and genetic predispositions [27].

The most commonly studied and associated Tabs with HCV and peg-INF- $\alpha$ induced thyroiditis in the literature are TPO and TG antibodies [3]. However, patients with destructive thyroiditis were also reported to have inhibitory TSHR-Abs[32]. The most prevalent Tabs in our study were TSHR-Abs and the lowest were TPO-Abs. Additionally, TPO-Abs were only detected during the course of therapy and at the end of treatment, suggesting a role for INF-a based therapy in their synthesis.

The differences between our findings and the previous reports could be due to the non-longitudinal design of our study and the small sample size, which may have underestimated the prevalence of TPO and TG antibodies. This variability can also be attributed to the diverse genetic predisposition of the subjects $[27,33]$. However, the detected significant difference in the prevalence of TSHR-Abs in our study suggests that the development of antibodies against TSH receptor are common in Saudi patients during $\mathrm{CHC}$ and during the treatment with Peg-INF- $\alpha$ based therapy.

Strong correlations between liver damage and thyroid disorders have been reported [34]. Non-alcoholic fatty liver diseases and abnormal liver enzymes are significantly associated with hypothyroidism and the the prevalence of liver diseases and enzymes increase steadily with increasing grades of hypothyroidism [34]. Furthermore, a decrease in serum T3 concentration and T3:T4 ratio is frequently observed in patients with liver cirrhosis probably due to impaired conversion of T4 to T3 in the liver [35]. Thyrotoxicosis is also associated with a variety of abnormalities of liver function [36] and results from a recent study suggests that low FT4 concentrations are associated with hepatic steatosis 
[37]. Serum TSH level was also significantly higher in nonalcoholic fatty liver diseases and it has also been suggested that measurement of FT3 and FT4 levels may all be useful as predictors of mortality in intensive care patients who have cirrhosis [38]. Our findigns are in agreement with the previous studies as they showed significant correlations between AST and ALT with both TSH and FT4 in patients with $\mathrm{CHC}$ and the strongest correlation was observed for thyroid hormones with APRI.

APRI is used as a predictor of liver fibrosis and cirrhosis in $\mathrm{CHC}$ as a replacement of liver biopsy in a substantial proportion of patients [39]. Several studies have confirmed the significant correlation between APRI and both the stage of liver fibrosis and the grade of activity [21]. Therefore, we suggest that the degree of liver damaged associated with $\mathrm{CHC}$ could be responsible for the non autoimmune thyroid abnormalities. However, investigating the prevalence of thyroid disorders associated with different stages of liver fibrosis and cirrhosis due to $\mathrm{CHC}$ is required to support our hypothesis.

Harada et al. confirmed that pathological expression of activin-A was associated with hyperthyroidism [17], while a significant increase of activin-A was associated with hypothyroidism and serum levels of activin-A were higher in goitrous patients with autoimmune thyroiditis[18]. The present work disagrees with the previous observations as it showed no significant difference in the concentrations of activin-A between autoimmune thyroiditis and euthyroid cases within each study groups. Similar results were also observed for follistatin and activin/ follistatin ratio $(A / F)$. The non-significant difference could be due the small sample size included in the study. However, the current study is the first to report that serum concentration of TSHR-Abs signifantly correlates positively with serum follistatin and negatively with activin- $A$ and $A / F$ ratio.

Activin-A has been established as a main regulator of immune responses $[20,21]$ and pathological activin-A levels have been associated several autoimmune diseases such as rheumatic diseases [40], systemic lupus erythematosus [41] and allergic airway diseases [42]. Therefore, we suggest that activin-A and/or follistatin are involved in HCV and Peg-INF- $\alpha$ induced autoimmune thyroiditis.

In conclusion, thyroid disorders induced by $\mathrm{HCV}$ and peg-INF- $\alpha$ treatment are common in Saudi patients, with higher prevalence in females and the majority is autoimmune in nature. Additionally, activin-A and/or follistatin could be involved in the induction/agrevation of TSH receptors antibodies. Further studies are needed to confirm the detected prevalence of thyroid disorders in our study and to explore the role of activins and their binding protein in hepatitis $\mathrm{C}$ induced thyroiditis.

\section{Acknowledgment}

The authors thank KACST for the financial support of the study (12-MED2302-10) under the National Science, Technology and Innovation Plan.

\section{REFERENCES}

1. Ghany MG, Strader DB, Thomas DL, et al. Diagnosis, management, and treatment of hepatitis C: an update. Hepatology 2009;49:1335-1374.

2. Tomer $\mathrm{Y}$, Blackard JT and Akeno N. Interferon alpha treatment and thyroid dysfunction. Endocrinol Metab Clin North Am 2007;36:1051-1066.

3. Tomer $Y$. Hepatitis $C$ and interferon induced thyroiditis. J Autoimmun 2010;34:322-326.

4. Andrade LJ, Atta AM, Atta ML, et al. Thyroid disorders in patients with chronic hepatitis $\mathrm{C}$ using interferon-alpha and ribavirin therapy. Braz J Infect Dis 2011;15:377-381.

5. Soppi E. Concurrent subacute thyroiditis and Graves disease. Duodecim 2012;128:1808-1810.

6. Hollowell JG, Staehling NW, Flanders WD, et al. Serum TSH, T(4), and thyroid antibodies in the United States population (1988 to 1994): National Health and Nutrition Examination Survey (NHANES III). J Clin Endocrinol Metab 2002;87:489-499.

7. Bostancı M and Taşkesen F. Thyroid dysfunction during pregnancy and evaluation of its results. J Clin Exp Invest 2011;2:6.

8. Karakas O, Karakas E, Cullu N, et al. Evaluation of patients with thyrotoxic autoimmune thyroiditis by color flow doppler ultrasonography. J Clin Exp Invest 2013;4:73-79.

9. Wong V, Fu AX, George J, et al. Thyrotoxicosis induced by alpha-interferon therapy in chronic viral hepatitis. Clin Endocrinol (Oxf) 2002;56:793-798.

10. Refaat BA, Bahathiq AO, Sockanathan S, et al. Production and localization of activins and activin type IIA and IIB receptors by the human endosalpinx. Reproduction 2004;128:249-255.

11. Werner $S$ and Alzheimer $C$. Roles of activin in tissue repair, fibrosis, and inflammatory disease. Cytokine Growth Factor Rev 2006;17:157-171.

12. Phillips DJ, de Kretser DM, and Hedger MP. Activin and related proteins in inflammation: not just interested bystanders. Cytokine Growth Factor Rev 2009;20:153164.

13. Sugino K, Mimura T, Ozaki O, et al. Preoperative change of thyroid stimulating hormone receptor antibody level: possible marker for predicting recurrent hyperthyroidism in patients with Graves' disease after subtotal thyroidectomy. World J Surg 1996;20:801-806; discussion 806-807. 
14. Franzen A, Piek E, Westermark B, et al. Expression of transforming growth factor-beta1, activin $A$, and their receptors in thyroid follicle cells: negative regulation of thyrocyte growth and function. Endocrinology 1999;140:4300-4310.

15. Bilezikjian LM, Corrigan AZ, and Vale W. Activin-A modulates growth hormone secretion from cultures of rat anterior pituitary cells. Endocrinology 1990;126:23692376.

16. Matsuo SE, Fiore AP, Siguematu SM, et al. Expression of SMAD proteins, TGF-beta/activin signaling mediators, in human thyroid tissues. Arq Bras Endocrinol Metabol 2010;54:406-412.

17. Harada K, Shintani Y, Sakamoto $Y$, et al. Serum immunoreactive activin $A$ levels in normal subjects and patients with various diseases. J Clin Endocrinol Metab 1996;81:2125-2130.

18. Morpurgo PS, Beck-Peccoz P, Reschini E, et al. Serum activin $A$ levels in different thyroid disorders. Thyroid 2002;12:1113-1117.

19. Kotajima A, Miyamoto $Y$, Tsuruo $M$, et al. Effects of activin $A$ on deoxyribonucleic acid synthesis, iodine metabolism, and cyclic adenosine monophosphate accumulation in porcine thyroid cells. Endocrinology 1995;136:1214-1218.

20. Refaat B, Ashshi AM, El-Shemi AG, et al. Effects of chronic hepatitis $C$ genotype 1 and 4 on serum activins and follistatin in treatment naive patients and their correlations with interleukin-6, tumour necrosis factoralpha, viral load and liver damage. Clin Exp Med 2014.

21. Refaat B, El-Shemi AG, Ashshi AM, et al. Serum activins and follistatin during the treatment of chronic hepatitis $C$ genotypes 1 and 4 and their correlations with viral load and liver enzymes: A preliminary report. Gastroenterol Res Pract 2014;2014:628683

22. Baloch Z, Carayon P, Conte-Devolx B, et al. Laboratory medicine practice guidelines. Laboratory support for the diagnosis and monitoring of thyroid disease. Thyroid 2003;13:3-126.

23. Vezali E, Elefsiniotis I, Mihas C, et al. Thyroid dysfunction in patients with chronic hepatitis C: virus- or therapyrelated? J Gastroenterol Hepatol 2009;24:1024-1029.

24. Mohran ZY, Abdel Kader NA, Abdel Moez AT, et al. Subclinical autoimmune thyroid disorders in Egyptian patients with untreated chronic hepatitis $C$ virus infection. J Egypt Soc Parasitol 2010;40:45-56.

25. Cesur S, Akin K, Albayrak F, et al. [Prevalence of extrahepatic illnesses in patients with chronic hepatitis $b$ and hepatitis c: retrospective study of 435 patients]. Mikrobiyol Bul 2003;37:187-193.

26. Nadeem A and Aslam M. Association of interferon-alpha and ribavirin-induced thyroid dysfunction with severity of disease and response to treatment in pakistani asian patients of chronic hepatitis C. Hepat Res Treat 2012;2012:864315.

27. Yan Z, Fan K, Fan Y, et al. Thyroid dysfunction in chinese patients with chronic hepatitis $C$ treated with interferon alpha: incidence, long-term outcome and predictive factors. Hepat Mon 2012;12:e6390.
28. Costelloe SJ, Wassef N, Schulz J, et al. Thyroid dysfunction in a UK hepatitis C population treated with interferon-alpha and ribavirin combination therapy. Clin Endocrinol (Oxf) 2010;73:249-256.

29. Huang JF, Chuang WL, Dai CY, et al. The role of thyroid autoantibodies in the development of thyroid dysfunction in Taiwanese chronic hepatitis $C$ patients with interferon-alpha and ribavirin combination therapy. J Viral Hepat 2006;13:396-401.

30. Tran HA, Jones TL, and Batey RG. The spectrum of thyroid dysfunction in an Australian hepatitis $\mathrm{C}$ population treated with combination Interferon-alpha2beta and Ribavirin. BMC Endocr Disord 2005;5:8.

31. Gehring S, Kullmer U, Koeppelmann S, et al. Prevalence of autoantibodies and the risk of autoimmune thyroid disease in children with chronic hepatitis $\mathrm{C}$ virus infection treated with interferon-alpha. World J Gastroenterol 2006;12:5787-5792.

32. Mandac JC, Chaudhry S, Sherman KE, et al. The clinical and physiological spectrum of interferon-alpha induced thyroiditis: toward a new classification. Hepatology 2006;43:661-672

33. Carella C, Mazziotti G, Amato G, et al. Clinical review 169: Interferon-alpha-related thyroid disease: pathophysiological, epidemiological, and clinical aspects. J Clin Endocrinol Metab 2004;89:3656-3661.

34. Chung HS, Cho SJ, and Park CS. Effects of liver function on ionized hypocalcaemia following rapid blood transfusion. J Int Med Res 2012;40:572-582.

35. El-Kabbany ZA, Hamza RT, Abd El Hakim AS, et al. Thyroid and Hepatic Haemodynamic Alterations among Egyptian Children with Liver Cirrhosis. ISRN Gastroenterol 2012;2012:595734.

36. Khan TM, Malik S, and Diju IU. Correlation between plasma thyroid hormones and liver enzymes level in thyrotoxic cases and controls in Hazara Division. J Ayub Med Coll Abbottabad 2010;22:176-179.

37. Ittermann $T$, Haring $R$, Wallaschofski $H$, et al. Inverse association between serum free thyroxine levels and hepatic steatosis: results from the Study of Health in Pomerania. Thyroid 2012;22:568-574.

38. Tas A, Koklu S, Beyazit $Y$, et al. Thyroid hormone levels predict mortality in intensive care patients with cirrhosis. Am J Med Sci 2012;344:175-179.

39. Wai CT, Greenson JK, Fontana RJ, et al. A simple noninvasive index can predict both significant fibrosis and cirrhosis in patients with chronic hepatitis $\mathrm{C}$. Hepatology 2003;38:518-526.

40. El-Gendi SS, Moniem AE, Tawfik NM, et al. Value of serum and synovial fluid activin $A$ and inhibin $A$ in some rheumatic diseases. Int J Rheum Dis 2010;13:273-279.

41. Torricelli M, Bellisai F, Novembri R, et al. High levels of maternal serum IL-17 and activin $A$ in pregnant women affected by systemic lupus erythematosus. Am J Reprod Immunol 2011;66:84-89.

42. Semitekolou M, Alissafi T, Aggelakopoulou M, et al. Activin-A induces regulatory $T$ cells that suppress $T$ helper cell immune responses and protect from allergic airway disease. J Exp Med 2009;206:1769-1785. 